\title{
Perancangan Basis Data Instrumen Bimbingan Konseling Alat Ungkap Pemahaman Diri Siswa
}

\author{
Database Design of Counseling Guidance Instrument \\ for Student's Self-Understanding Revealing Tools
}

\author{
Febria Sri Handayani*1, Meidyan Permata Putri² \\ ${ }^{1,2}$ Sistem Informasi, STMIK PalComTech \\ E-mail: *1febria_sri@palcomtech.ac.id, ${ }^{2}$ meidyan_permata@palcomtech.ac.id
}

\begin{abstract}
Abstrak
Dokumen pengembangan kurikulum 2013 merupakan salah satu sumber acuan peningkatan mutu sumber daya manusia di sekolah. Dalam proses bimbingan dan konseling di sekolah, salah satu instrumen yang digunakan untuk melakukan penelusuran minat siswa adalah alat ungkap pemahaman diri siswa. Alat ini merupakan salah satu alat untuk menilai kualitas belajar siswa. Biasanya aktivitas ini dilakukan secara temu muka antara guru bimbingan konseling (BK) dengan siswa maupun dengan orang tua atau wali siswa. Tingginya kegiatan distribusi angket pemahaman diri siswa oleh guru BK kepada para siswa secara manual merupakan salah satu masalah yang hampir tak bisa dihindari. Hal ini terjadi karena setelah proses distribusi, guru BK harus merekap satu persatu angket tersebut untuk dinilai dan dilaporkan baik kepada kepala sekolah maupun orang tua siswa. Untuk itu dibutuhkan sebuah aplikasi untuk meningkatkan efisiensi dan efektifitas kerja guru BK. Selain itu, aplikasi ini juga membantu guru BK dalam mengolah data pemahaman diri siswa di sekolah sebagai salah satu instrumen bimbingan konseling. Penelitian dimulai dari tahap perancangan basis data menggunakan metode Database Life Cycle (DBLC). Basis data ini dirancang untuk aplikasi berbasis web. Perancangan dilakukan secara konseptual, logikal, dan fisikal. Perancangan basis data ini menghasilkan validasi model data dan relasi antar entitas yang terkait.
\end{abstract}

Kata Kunci — konseptual, logikal, fisikal, basis data, DBLC

\begin{abstract}
The curriculum development document 2013 is one of the sources references for improving the human resource quality in schools. In the process of guidance and counseling in schools, the instruments used to conduct interest tracing students one of them using tools express self-understanding of students. Where this tool is one tool to assess the qualityof student learning. Usually this activity is done directly face-to-face between counseling teachers (BK) with students and with parents or guardians of students. The high student self-understanding questionnaire distribution by BK teachers to the students at school is one of the almost inevitable problems. This happens because after the questionnaire distribution process, the teacher BK must recap each questionnaire to be assessed and reported to both the principal and parents. Therefore, an application is needed to improve the efficiency and effectiveness of BK teachers. In addition, this application helps BK teachers in processing student self-understanding data in school as one of the counseling guidance instruments. Research starts from database design stage using Database Life Cycle (DBLC) method. Where this database is designed for web based applications. The design is done conceptually, logically, and physically. The design of this database generates validation of data models and relationships between related entities.
\end{abstract}

Keywords - Conceptual, logical, fisical, database, DBLC 


\section{PENDAHULUAN}

Pemberlakukan kurikulum 2013 sejak bulan desember 2014, merupakan salah satu pondasi pelaksanaan pembelajaran model baru di sekolah. Peningkatan mutu siswa sebagai peserta didik di sekolah merupakan salah satu tujuan utamanya. Hal ini juga sejalan dengan tujuan pembinaan kesiswaan yang diatur dalam peraturan menteri pendidikan nasional Republik Indonesia No. 39 Tahun 2008 [1]. Dimana dalam peraturanmenteri tersebut disebutkan salah satu tujuan pembinaan kesiswaan adalah mengembangkan dan mengaktualisasikan potensi siswa secara optimal dan terpadu guna mencapai prestasi unggulan sesuai bakat, minat dan kreativitas. Oleh karena itu, peran serta unit bimbingan dan konseling di sekolah sangat dibutuhkan guna melakukan pendekatan ke siswa untuk pencapaian tujuan pembinaan kesiswaan tersebut. Pendekatan tersebut dilakukan untuk mengetahui seberapa jauh pemahaman siswa terhadap kualitas dirinya sendiri. Pemahaman kualitas tersebut meliputi pemahaman diri, nilai kehidupan, pengenalan lingkungan pendidikan, dan pengenalan lingkungan pekerjaan. Hal ini penting untuk diketahui guna mendukung tujuan kurikulum 2013 yaitu peningkatan kualitas diri dan belajar siswa di sekolah.

Beberapa pengalaman selama observasi kegiatan unit bimbingan konseling di sekolah menunjukkan bahwa tingkat penggunaan kertas untuk penyebaran angket pemahaman diri cenderung tinggi. Pengolahan data pemahaman diri siswa pun terkadang dilakukan secara manual maupun menggunakan produk Microsoft Office. Sesuatu yang dirasa cukup merepotkan bagi guru BK adalah ketika menginterpretasikan dan melaporkan hasil pengolahan data dan penilaian angket pemahaman diri siswa. Oleh karena itu dibutuhkan sebuah alat bantu pengolahan data untuk mengurangi semua permasalahan yang sering terjadi.

Aplikasi sebagaisalah satu alat bantu pengolahan data membutuhkan media penyimpanan data yang baik. Basis data merupakan kumpulan tabel yang saling berelasi [2]. Kecepatan serta kemudahan pengambilan data merupakan salah satu tujuan pentingnya basis data dipelihara dengan baik. Beberapa penelitian tentang perancangan basis data aplikasi, diantaranya tentang perancangan basis data sistem informasi penggajian. Perancangan basis data dilakukan dengan menerapkan normalisasi dan mengutamakan jenis relasi yang mungkin terjadi antar entitas. Dengan mendahulukan seluruh entitas yang berelasi secara one to one (1-1), one to many (1-M), dan many to many (M-M), didapatkanlah sebuah rancangan basis data secara fisikal. Rancangan basis data fisik yang dihasilkan terdiri dari tujuh tabel yang saling berelasi, diantaranya tabel golongan, tabel jabatan fungsional akademik, tabel struktural, tabel jabatan khusus, tabel pendidikan, tabel dosen, dan tabel gaji [3].

Selain itu, ada pula yang melakukan penelitian tentang perancangan sistem basis data pada klinik. Penelitian ini bertujuan untuk melakukan analisa dan merancang basis data untuk mendukung kebutuhan informasi pendaftaran dan pengobatan pasien pada klinik kesehatan. Perancangan basis datanya juga dilakukan secara konseptual, logikal, dan fisikal. Sistem basis data yang dihasilkan mampu menyimpan data terintegrasi dan mampu memenuhi kebutuhan informasi klinik. Sistem basis data ini juga diharapkan mampu meningkatkan pelayanan kesehatan terhadap para pasiennya [4].

Penelitian tentang perancangan basis data website wedding organizer sekapur sirih juga pernah dilakukan. Perancangan basis data website ini juga menggunakan langkah-langkah yang sama dengan penelitian sebelumnya. Perancangan secara konseptual, logikal, dan fisikal juga dilakukan untuk mendapatkan rancangan basis data website wedding organizer sekapur sirih. Dengan alasanbelum adanya alat pengolahan data dan media promosi wedding organizer sekapur sirih inilah yang menjadi fondasi dilakukannya perancanganbasis data website wedding organizer sekapur sirih [5].

Dengan merunut pada penelitian terdahulu, penelitian ini menghasilkan rancangan basis data untuk proses pembuatan aplikasi alat ungkap pemahaman diri siswa. Dimana aplikasi ini dapat digunakan oleh guru BK di sekolah sebagai salah satu instrumen penelusuran minat siswa 


\section{METODE PENELITIAN}

Penelitian ini menggunakan metode Database Life Cycle (DBLC) [3,9,10] untuk perancangan basis datanya. Perancangan basis data aplikasi alat ungkap pemahaman diri siswa ini dilakukan berdasarkan langkah-langkah berikut, diantaranya [3,4,7]:

1. Melakukan observasi, wawancara, studi pustaka, serta beberapa teknik pengumpulan data lainnya guna mendapatkan data-data yang diperlukan.

2. Melakukan analisa kebutuhan data yang meliputi kebutuhan user dan aplikasinya.

3. Melakukan perancangan basis data secara konseptual.

4. Melakukan perancangan basis data secara logikal (data model mapping).

5. Melakukan perancangan basis data secara fisikal. Dimana hasil perancangan pada tahap ini akan digambarkan dalam bentuk desain tabel menggunakan aplikasi PHPMyAdmin 2.5.10.

6. Melakukan implementasi basis data untuk mengetahui kelayakan basis data yang dirancang.

7. Merumuskan kesimpulan terhadap hasil penelitian, dan memberikan saran untuk penelitian selanjutnya yang berkaitan dengan hasil penelitian ini.

Gambar 1 merupakan alur penelitian yang digunakan untuk merancang basis data aplikasi alat ungkap pemahaman diri siswa dalam instrument bimbingan konseling [3,4].

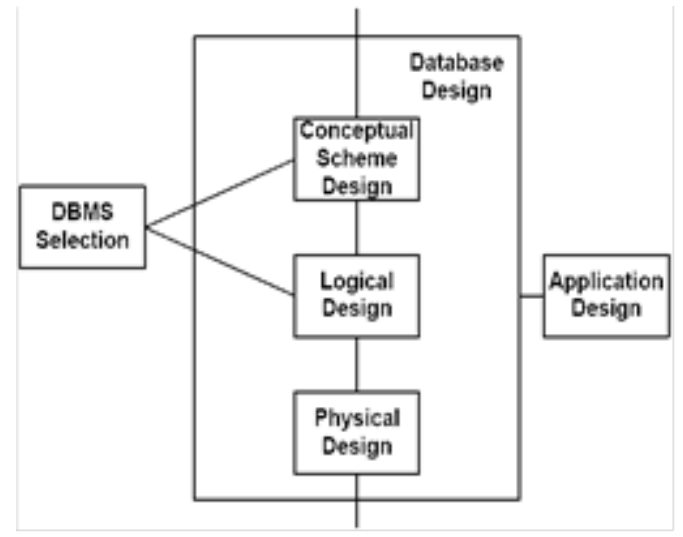

Kesimp Gambar 1. Alur Penelitian

\section{HASIL DAN PEMBAHASAN}

\subsection{Analisa Kebutuhan Data}

\subsubsection{Hasil Pengumpulan Data}

Dari kegiatan observasi pada kegiatan Bimbingan Konseling (BK) di sekolah dan juga kegiatan wawancara dengan guru BK, data-data yang berhasil dikumpulkan oleh penulis didapat dalam bentuk berkas, diantaranya:

1. Formulir angket pemahaman diri siswa.

2. Pedoman pengolahan data angket pemahaman diri siswa oleh guru.

3. Rekapitulasi hasil distribusi angket pemahaman diri siswa.

\subsubsection{Analisis Kebutuhan Pengguna (user)}

Analisa awal pada kegiatan bimbingan konseling di sekolah khususnya penilaian pemahaman diri siswa terdapat beberapa permasalahan akibat adanya aktivitas pengolahan data secara tradisional. Pihak sekolah masih berorientasi pada full paper untuk proses pengolahan data. 
Dimulai dari distribusi angket pemahaman diri siswa yang dibagikan untuk siswa dalam bentuk lembaran kertas yang datanya diisi secara tertulis oleh siswa. Penghitungan skor dan pengolahan data hasil distribusi angket oleh guru BK juga masih dilakukan secara manual, begitu juga dengan pelaporan hasilnya.

Berdasarkan analisis sistem yang berjalan, maka beberapa hal berikut dapat dijadikan panduan untuk perancangan basis data aplikasi alat ungkap pemahaman diri siswa, diantaranya:

1. Dibutuhkan alat bantu pengolahan data bimbingan konseling khususnya penilaian pemahaman diri siswa. Pengolahan data dalam jumlah besar dan intensif jika tidak ditangani dengan baik akan berdampak buruk bagi pihak sekolah. Redudansi data, ketidakakuratan laporan, serta kehilangan data pun dapat terjadi dengan adanya manajemen data yang buruk.

2. Dibutuhkan integrasi sistem yang terkoordinasi agar sesuai dengan kebutuhan pengolahan data bimbingan konseling di sekolah.

3. Dibutuhkan pelaporan hasil pengolahan data yang cepat, tepat dan akurat sesuai dengan kebutuhan masing-masing user.

4. Dibutuhkan pembatasan hak akses terhadap informasi dan proses pengolahan data yang dapat dilakukan pada aplikasi alat ungkap pemahaman diri siswa ini.

\subsubsection{Alternatif Pemecahan Masalah}

Berdasarkan analisis permasalahan yang terjadi selama ini serta mengingat pentingnya mengutamakan kebutuhan pengguna, maka berikut ini beberapa alternatif pemecahan masalah yang diusulkan, diantaranya:

1. Merancang sistem basis data yang dilengkapi dengan sistem keamanan seperti autoritas dan autentikasi pengguna. Hal ini dilakukan guna membatasi hak akses pengguna. Hanya guru BK dan siswa yang terdaftar di sekolah itu saja yang bisa mengakses dan mengolah data pada aplikasi alat ungkap pemahaman diri siswa ini. Guru BK dapat mengakses dan mengolah data menggunakan Nomor Induk Pegawai (NIP). Siswa dapat mengakses dan mengolah data menggunakan Nomor Induk Siswa Nasional (NISN).

2. Merancang sistem basis data yang memudahkan guru BK dan siswa untuk mendapatkan laporan hasil pengolahan data pemahaman diri siswa.

3. Merancang sistem basis data berbasis web agar dapat diintegrasikan dengan aplikasi berbasis web guna memudahkan pengguna (user) mengakses data kapan pun dan dapat menggunakan perangkat komunikasi yang dapat terhubung dengan internet.

Oleh karena itu, perancangan basis data aplikasi alat ungkap pemahaman diri siswa ini dibuat dengan mengacu pada kebutuhan data yang bersifat integrated dan shared. Dikatakan integrated jika dalam basis data dapat dilakukan penggabungan beberapa file data yang berbeda, sedangkan shared maksudnya data individual dalam basis data dapat digunakan secara bersamasama antara beberapa pengguna yang berbeda [6].

\subsection{Perancangan Basis Data Secara Konseptual}

Perancangan basis data secara konseptual untuk aplikasi alat ungkap pemahaman diri dilakukan dengan melakukan identifikasi tipe entitas dan relasi antar entitas dalam basis data aplikasi alat ungkap pemahaman diri siswa. Tabel 1 dapat menjelaskan proses identifikasi tipe entitas yang dibutuhkan dalam basis data aplikasi alat ungkap pemahaman diri siswa ini. Kemudian langkah selanjutnya adalah mengidentifikasi atribut beserta kandidat key-nya. Aktivitas normalisasi entitas beserta atributnya dilakukan untuk mendapatkan model konseptual basis data yang baik. Hasil akhir dari proses perancangan basis data secara konseptual ini akan menghasilkan sebuah validasi model konseptual basis data yang dapat dilihat pada Gambar 2. 
Tabel 1. Identifikasi Tipe Entitas

\begin{tabular}{|c|c|c|c|}
\hline Nama Entitas & Alias & Deskripsi & Kejadian \\
\hline Tb_Siswa & Siswa & $\begin{array}{l}\text { Menggambarkan data siswa } \\
\text { yang terdaftar pada sekolah } \\
\text { yang bers angkutan. }\end{array}$ & $\begin{array}{l}\text { Semua data siswa diolah oleh } \\
\text { unit Bimbingan Konseling di } \\
\text { sekolah yang bersangkutan. }\end{array}$ \\
\hline Tb_GuruBK & Guru BK & $\begin{array}{l}\text { Menggambarkan data guru } \\
\text { BK yang terdaftar pada } \\
\text { sekolah yang bersangkutan. }\end{array}$ & $\begin{array}{l}\text { Semua data guru BK yang } \\
\text { mengolah data siswa dan angket } \\
\text { pemahaman diri siswa dalam } \\
\text { basis data aplikasi. }\end{array}$ \\
\hline Tb_AngketPDS & $\begin{array}{l}\text { Angket } \\
\text { Pemahaman } \\
\text { Diri Siswa } \\
\text { (PDS) }\end{array}$ & $\begin{array}{l}\text { Menggambarkan data } \\
\text { pemahaman diri masing- } \\
\text { masing sis wa yang dinilai } \\
\text { oleh guru BK di sekolah } \\
\text { tersebut. }\end{array}$ & $\begin{array}{l}\text { Semua data yang berkaitan } \\
\text { dengan penilaian pemahaman } \\
\text { diri siswa. }\end{array}$ \\
\hline Tb_PernyataanPDS & $\begin{array}{l}\text { Detil } \\
\text { Pernyataan } \\
\text { Dalam } \\
\text { Angket } \\
\text { PDS } \\
\end{array}$ & $\begin{array}{l}\text { Merupakan entitas yang } \\
\text { berisi detil pernyataan yang } \\
\text { ada di dalam angket PDS. }\end{array}$ & $\begin{array}{l}\text { Satu angket terdiri dari satu atau } \\
\text { lebih pernyataan. }\end{array}$ \\
\hline Tb_Sifat & Sifat & $\begin{array}{l}\text { Merupakan entitas yang } \\
\text { berisi sifat-sifat yang } \\
\text { menunjang dan menghambat } \\
\text { pencapaian cita-cita siswa. }\end{array}$ & $\begin{array}{l}\text { Satu angket yang berisi masing- } \\
\text { masing } 5 \text { sifat yang menunjang } \\
\text { dan menghambat pencapaian } \\
\text { cita-cita siswa. }\end{array}$ \\
\hline Tb_NilaiAngket & $\begin{array}{l}\text { Rekap } \\
\text { Angket } \\
\text { PDS }\end{array}$ & $\begin{array}{l}\text { Menggambarkan data hasil } \\
\text { penilaian angket PDS yang } \\
\text { telah didistribusikan ke } \\
\text { siswa. Penilaian dilakukan } \\
\text { oleh Guru BK. }\end{array}$ & $\begin{array}{l}\text { Semua data hasil pengolahan dan } \\
\text { perhitungan skor terhadap setiap } \\
\text { pertanyaan dalam angket PDS. }\end{array}$ \\
\hline Tb_User & User & $\begin{array}{l}\text { Merupakan entitas yang } \\
\text { berisi data virtual pengguna } \\
\text { aplikasi (guru BK). }\end{array}$ & $\begin{array}{l}\text { Semua data yang berhubungan } \\
\text { dengan data virtual guru BK. }\end{array}$ \\
\hline
\end{tabular}


Citec Journal, Vol. 4, No. 2, Februari 2017 - April 2017

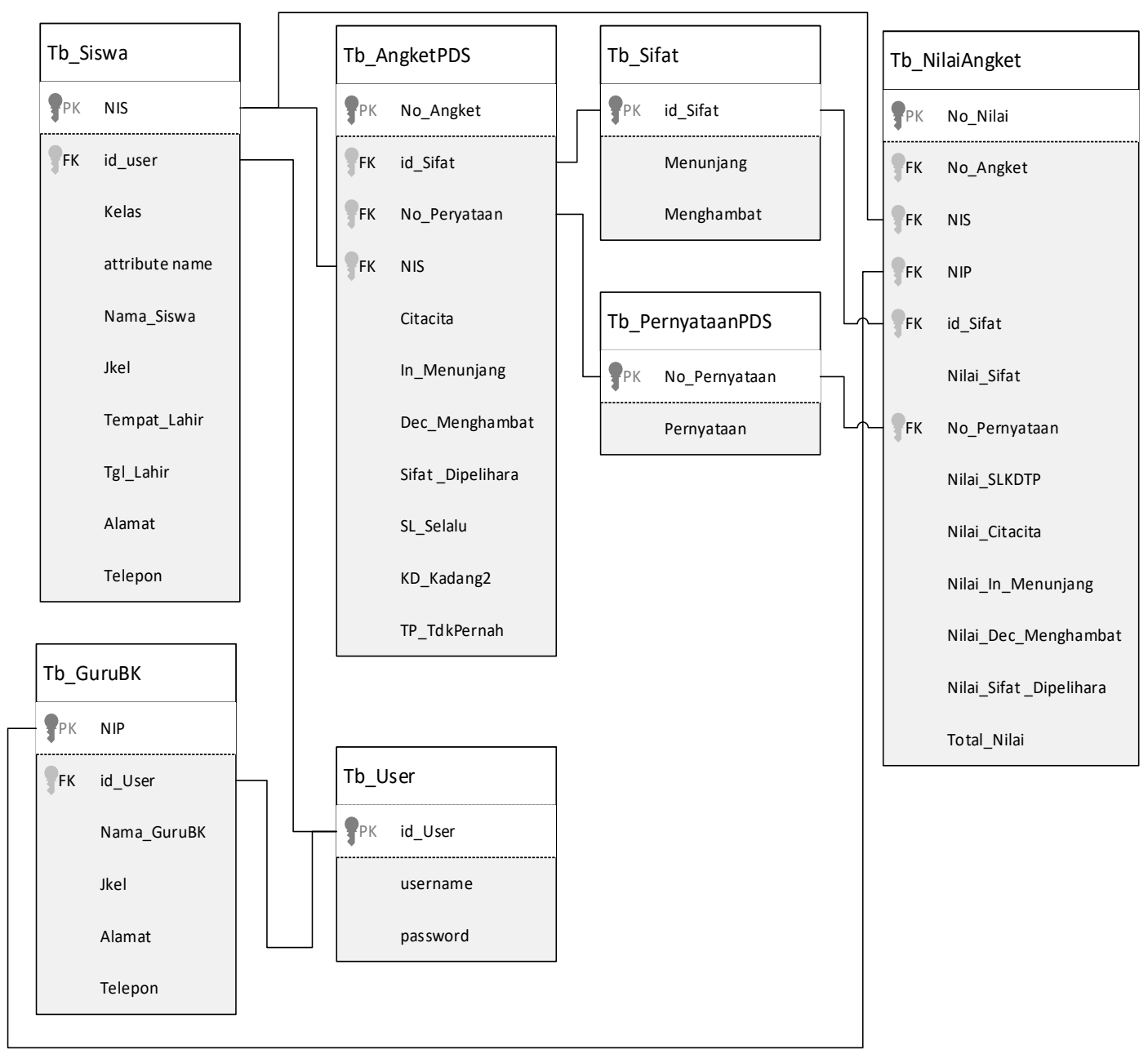

Gambar 2. Validasi Model Konseptual Basis Data Aplikasi Alat Ungkap Pemahaman Diri Siswa

Setelah melakukan validasi model konseptual basis data aplikasi alat ungkap pemahaman diri siswa, maka langkah selanjutnya adalah menentukan domain atribut. Domain adalah seluruh kemungkinan nilai yang dapat diberikan ke suatu atribut [7]. Data dari pemeriksaan berkas yang dikumpulkan akan menjadi atribut atau field dari tabel [8]. Tabel 2 mendeskripsikan bahwa domain dapat mengindikasikan tipe data yang harus diberikan untuk setiap field yang ada di dalam tiap entitas atau tabel.

Tabel 2. Domain Atribut

\begin{tabular}{|l|l|l|}
\hline Nama Tabel & \multicolumn{1}{|c|}{ Atribut } & \multicolumn{1}{c|}{ Domain } \\
\hline Tb_User & id_User & $\begin{array}{l}\text { String dengan panjang maksimal 6 karakter } \\
\text { adm01, adm02, ..., user01, user02, .. \}. }\end{array}$ \\
\cline { 2 - 3 } & Username & $\begin{array}{l}\text { String dengan panjang maksimal 12 karakter } \\
\text { (kombinasi huruf dan angka, tanpa simbol khusus } \\
\text { lainnya). }\end{array}$ \\
\cline { 2 - 3 } & Password & $\begin{array}{l}\text { String dengan panjang minimal 5 karakter } \\
\text { (misalnya nomor induk siswa (NIS)) dan maksimal }\end{array}$ \\
& 16 karakter (misalnya nomor induk pegawai guru \\
& BK(NIP)) \{11202, ..., 19620102198601, ... \}. \\
\hline
\end{tabular}


Tabel 2. Lanjutan

\begin{tabular}{|c|c|c|}
\hline Nama Tabel & Atribut & Domain \\
\hline \multirow[t]{9}{*}{ Tb_Siswa } & NIS & $\begin{array}{l}\text { String dengan panjang maksimal } 5 \text { karakter } \\
\{11202,12023, \ldots\}\end{array}$ \\
\hline & id_User & $\begin{array}{l}\text { Diambil dari atribut id_User yang berasal dari } \\
\text { Tb_User. Berisi String dengan panjang maksimal } 6 \\
\text { karakter }\{\text { adm01, adm02, ..., user01, user02, ... \}. }\end{array}$ \\
\hline & Kelas & $\begin{array}{l}\text { String dengan panjang maksimal } 7 \text { karakter }\{\text { VII.1, } \\
\text { VIII.12, IX.3, ... }\end{array}$ \\
\hline & Nama_Siswa & String dengan panjang maksimal 30 karakter. \\
\hline & Jkel & $\begin{array}{l}\text { String dengan panjang maksimal } 1 \text { karakter, berupa } \\
\text { pilihan inisial jenis kelamin (gender) laki-laki atau } \\
\text { perempuan }\{\mathrm{P} / \mathrm{L}\} \text {. }\end{array}$ \\
\hline & Tempat_Lahir & $\begin{array}{l}\text { String dengan panjang maksimal } 15 \text { karakter } \\
\{\text { Palembang, Tanjung Tebat, ... }\end{array}$ \\
\hline & Tgl_Lahir & $\begin{array}{l}\text { Date dengan panjang maksimal } 10 \text { karakter } \text { \{dd- } \\
\text { mm-yyyy }\end{array}$ \\
\hline & Alamat & String dengan panjang maksimal 50 karakter. \\
\hline & Telepon & $\begin{array}{l}\text { String dengan panjang maksimal } 15 \text { karakter } \\
\{081376541234\}\end{array}$ \\
\hline \multirow[t]{6}{*}{ Tb_GuruBK } & NIP & $\begin{array}{l}\text { String dengan panjang maksimal } 16 \text { karakter nomor } \\
\text { induk pegawai dari guru BK. }\end{array}$ \\
\hline & id_User & $\begin{array}{l}\text { Diambil dari atribut id_User yang berasal dari } \\
\text { Tb_User. Berisi String dengan panjang maksimal } 6 \\
\text { karakter }\{\text { adm01, adm02, ..., user01, user02, ... \}. }\end{array}$ \\
\hline & Nama_GuruBK & String dengan panjang maksimal 30 karakter. \\
\hline & Jkel & $\begin{array}{l}\text { String dengan panjang maksimal } 1 \text { karakter, berupa } \\
\text { pilihan inisial jenis kelamin (gender) laki-laki atau } \\
\text { perempuan }\{\mathrm{P} / \mathrm{L}\} \text {. }\end{array}$ \\
\hline & Alamat & String dengan panjang maksimal 50 karakter. \\
\hline & Telepon & $\begin{array}{l}\text { String dengan panjang maksimal } 15 \text { karakter } \\
\{081376541234\}\end{array}$ \\
\hline \multirow[t]{11}{*}{ Tb_AngketPDS } & No_Angket & $\begin{array}{l}\text { String dengan panjang maksimal } 5 \text { karakter }\{\text { A001, } \\
\ldots \text {... }\end{array}$ \\
\hline & Id_sifat & $\begin{array}{l}\text { Diambil dari atribut id_Sifat yang berasal dari } \\
\text { Tb_Sifat. Berisi String dengan panjang maksimal } 5 \\
\text { karakter }\{\text { MJ01, MH01, ... }\}\end{array}$ \\
\hline & No_Pernyataan & $\begin{array}{l}\text { Diambil dari atribut No_Pernyataan yang berasal } \\
\text { dari Tb_PernyataanPDS. Berisi String dengan } \\
\text { panjang maksimal } 5 \text { karakter }\{\text { P01, P02, ...\}. }\end{array}$ \\
\hline & NIS & $\begin{array}{l}\text { Diambil dari atribut NIS yang berasal dari } \\
\text { TB_Siswa. Berisi String dengan panjang maksimal } \\
5 \text { karakter }\{11202,12023, \ldots\} .\end{array}$ \\
\hline & Citacita & $\begin{array}{l}\text { Mengindikasikan profesi yang ingin dijalani siswa. } \\
\text { Data berupa String dengan panjang maksimal } 20 \\
\text { karakter. }\end{array}$ \\
\hline & In_Menunjang & String dengan panjang maksimal 20 karakter. \\
\hline & Dec_Menghambat & String dengan panjang maksimal 20 karakter. \\
\hline & Sifat_Dipelihara & String dengan panjang maksimal 20 karakter. \\
\hline & SL_Selalu & $\begin{array}{l}\text { Bit bernilai } 1 \text { jika dipilih, bernilai } 0 \text { jika tidak } \\
\text { dipilih. }\end{array}$ \\
\hline & KD_Kadang2 & $\begin{array}{l}\text { Bit bernilai } 1 \text { jika dipilih, bernilai } 0 \text { jika tidak } \\
\text { dipilih. }\end{array}$ \\
\hline & TP_TdkPernah & $\begin{array}{l}\text { Bit bernilai } 1 \text { jika dipilih, bernilai } 0 \text { jika tidak } \\
\text { dipilih. }\end{array}$ \\
\hline
\end{tabular}


Citec Journal, Vol. 4, No. 2, Februari 2017 - April 2017

Tabel 2. Lanjutan

\begin{tabular}{|c|c|c|}
\hline Nama Tabel & Atribut & Domain \\
\hline \multirow[t]{4}{*}{ Tb_Sifat } & Id_Sifat & $\begin{array}{l}\text { String dengan panjang maksimal } 5 \text { karakter }\{\text { MJ01, } \\
\text { MH01, ...\}. }\end{array}$ \\
\hline & No_Angket & $\begin{array}{l}\text { Diambil dari atribut No_Angket yang berasal dari } \\
\text { Tb_AngketPDS. Berisi String dengan panjang } \\
\text { maksimal } 5 \text { karakter }\{\text { A001, ... }\}\end{array}$ \\
\hline & Menunjang & String dengan panjang maksimal 30 karakter. \\
\hline & Menghambat & String dengan panjang maksimal 30 karakter. \\
\hline \multirow[t]{3}{*}{ Tb_PernyataanPDS } & No_Pernyataan & $\begin{array}{l}\text { String dengan panjang maksimal } 5 \text { karakter }\{\mathrm{P} 01 \text {, } \\
\mathrm{P} 02, \ldots\} \text {. }\end{array}$ \\
\hline & No_Angket & $\begin{array}{l}\text { Diambil dari atribut No_Angket yang berasal dari } \\
\text { Tb_AngketPDS. Berisi String dengan panjang } \\
\text { maksimal } 5 \text { karakter }\{\text { A001, ... }\} \text {. }\end{array}$ \\
\hline & Pernyataan & String dengan panjang maksimal 30 karakter. \\
\hline \multirow[t]{13}{*}{ Tb_NilaiAngket } & No_Nilai & $\begin{array}{l}\text { String dengan panjang maksimal } 5 \text { karakter }\{\text { N001, } \\
\text { N002, ... }\} \text {. }\end{array}$ \\
\hline & No_Angket & $\begin{array}{l}\text { Diambil dari atribut No_Angket yang berasal dari } \\
\text { Tb_AngketPDS. Berisi String dengan panjang } \\
\text { maksimal } 5 \text { karakter }\{\text { A001, ... }\} \text {. }\end{array}$ \\
\hline & NIS & $\begin{array}{l}\text { Diambil dari atribut NIS yang berasal dari } \\
\text { Tb_Siswa. Berisi String dengan panjang maksimal } \\
5 \text { karakter }\{11202,12023, \ldots\} \text {. }\end{array}$ \\
\hline & NIP & $\begin{array}{l}\text { Diambil dari atribut NIP yang berasal dari } \\
\text { Tb_GuruBK. Berisi String dengan panjang } \\
\text { maksimal } 16 \text { karakter nomor induk pegawai dari } \\
\text { guru BK. }\end{array}$ \\
\hline & Id_Sifat & $\begin{array}{l}\text { Diambil dari atribut id_Sifat yang berasal dari } \\
\text { Tb_Sifat. Berisi String dengan panjang maksimal } 5 \\
\text { karakter }\{\text { MJ01, MH01, ...\}. }\end{array}$ \\
\hline & Nilai_Sifat & Byte dengan panjang maksimal 2 digit angka. \\
\hline & No_Pernyataan & $\begin{array}{l}\text { Diambil dari atribut No_Pernyataan yang berasal } \\
\text { dari Tb_PernyataanPDS. Berisi String dengan } \\
\text { panjang maksimal } 5 \text { karakter }\{\mathrm{P} 01, \mathrm{P} 02, \ldots\} \text {. }\end{array}$ \\
\hline & Nilai_SLKDTP & Byte dengan panjang maksimal 2 digit angka. \\
\hline & Nilai_Citacita & Byte dengan panjang maksimal 2 digit angka. \\
\hline & Nilai_In_Menunjang & Byte dengan panjang maksimal 2 digit angka. \\
\hline & Nilai_Dec_Menghambat & Byte dengan panjang maksimal 2 digit angka. \\
\hline & Nilai_Sifat_Dipelihara & Byte dengan panjang maksimal 2 digit angka. \\
\hline & Total_Nilai & Integer dengan panjang maksimal 3 digit angka. \\
\hline
\end{tabular}

\subsection{Perancangan Basis Data Secara Logikal}

Berikut ini langkah perancangan basis data secara logikal untuk aplikasi alat ungkap pemahaman diri siswa:

1. Melakukan normalisasi database pada tiap entitas.

2. Membuat turunan tabel/ entitas untuk menyederhanakan implementasi rancangan awal model konseptual.

3. Menentukan relasi antar entiti beserta foreign key-nya.

Normalisasi database dilakukan untuk menghilangkan kemungkinan redudansi dan inkonsistensi data. Dengan melakukan normalisasi database ini, kita dapat juga melakukan validasi terhadap relasi yang mungkin terjadi antar entitas. 
Berikut ini adalah tahapan normalisasi database yang dilakukan untuk rancangan basis data aplikasi alat ungkap pemahaman diri siswa, diantaranya:

1. Bentuk Un-Normal

Tb_AngketPDS \{No_Angket, NIS, Pernyataan 1 sampai Pernyataan 28 disertai pilihan SL_Selalu, pilihan KD_Kadang2, dan pilihan TP_TdkPernah, Citacita, Sifat Menunjang 1 sampai Sifat Menunjang 5, Sifat Menghambat 1 sampai Sifat Menghambat 5, in_Menunjang, dec_Menghambat, Sifat_dipelihara\}.

2. Bentuk Normal Pertama (1NF)

Pada langkah ini dilakukan penormalan untuk menghilangkan redudansi terhadap penginputan data pernyataan yang berjumlah 28 pernyataan, 5 sifat yang menunjang pencapaian cita-cita, dan 5 sifat yang menghambat pencapaian cita-cita.

Tb_PernyataanPDS $\{*$ No_Pernyataan, **No_Angket, Pernyataan $\}$

Tb_Sifat $\{*$ id_Sifat, $* *$ No_Angket, Menunjang, Menghambat $\}$

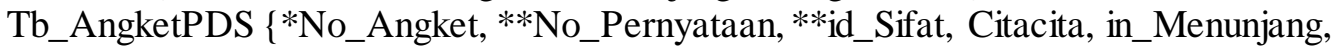
dec_Menghambat, Sifat_Dipelihara

Konsep awal dan hasil validasi relasi antar entitas dalam perancangan basis data secara logikal dapat dilihat pada Gambar 3 dan Gambar 4, yang mendeskripsikan tentang relasi antara entitas Tb_Sifat dan entitas Tb_PernyataanPDS dengan entitas Tb_AngketPDS.

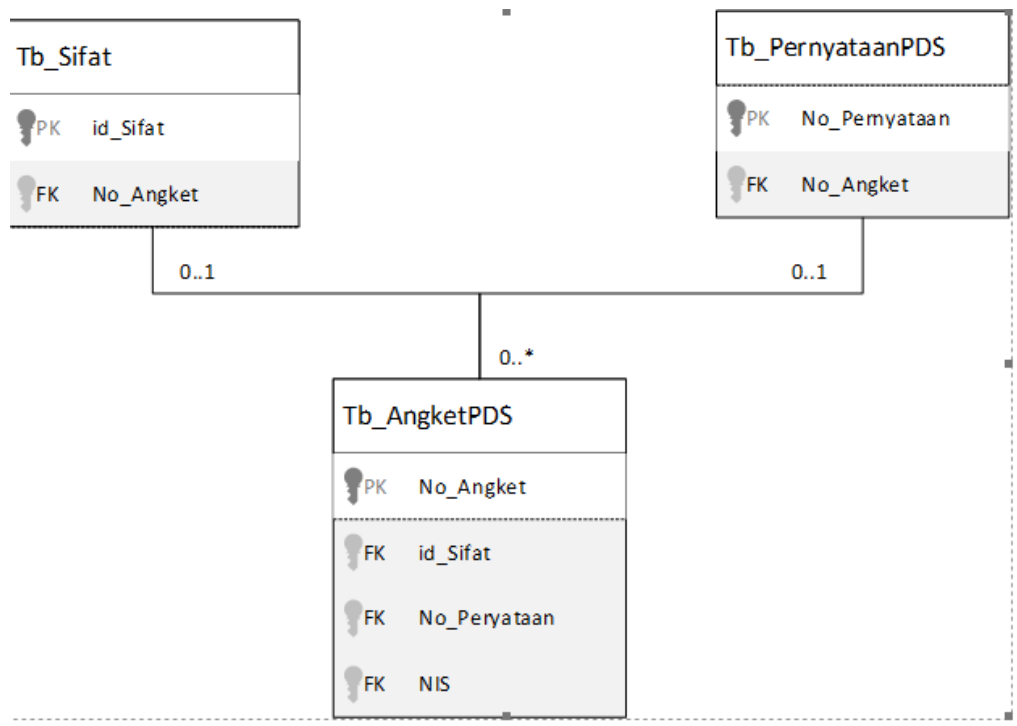

Gambar 3. Konsep Awal Relasi Entitas Tb_Sifat dan Entitas Tb_PernyataanPDS dengan Entitas Tb_AngketPDS

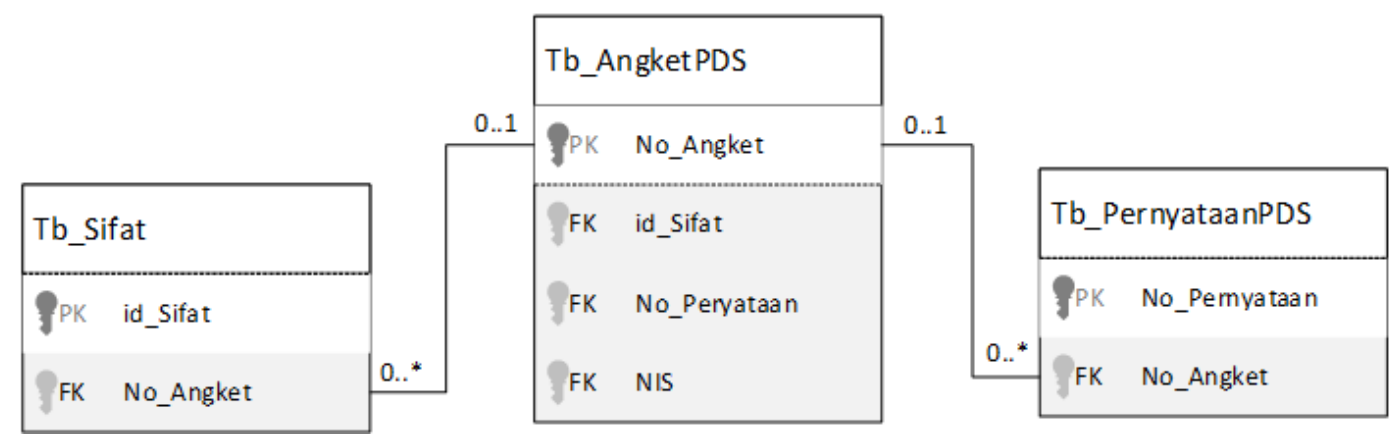

Gambar 4. Validasi Relasi Entitas Tb_Sifat dan Entitas Tb_PernyataanPDS dengan Entitas Tb_AngketPDS 


\subsection{Perancangan Basis Data Secara Fisikal}

Perancangan basis data aplikasi alat ungkap pemahaman diri siswa secara fisikal dilakukan dengan cara mengimplementasikan rancangan basis data logikal menggunakan Database Manajemen System (DBMS) [9]. Perancangan basis data fisikal menghasilkan deskripsi implementasi basis data pada penyimpanan sekunder, menggambarkan hubungan dasar, organisasi file, dan indeks yang digunakan untuk mencapai akses yang efisien terhadap data dan setiap kendala integritas terkait dan langkah-langkah keamanan [11].

Hasil rancangan basis data fisik ini dapat disimpan pada media penyimpanan eksternal yang sesuai dengan DBMS yang digunakan. Dalam hal ini ada beberapa hal yang harus diperhatikan dalam proses perancangan basis data secara fisikal, diantaranya:

1. Memperkirakan kapasitas disk berkaitan dengan tipe dan ukuran atribut dalam entitas.

2. Menganalisis transaksi data yang mungkin terjadi antar entitas.

3. Merancang mekanisme keamanan data.

4. Merancang user views.

5. Mempertimbangkan pengendalian terhadap kemungkinan redudansi data pada masingmasing entitas.

Pada penelitian ini digunakan aplikasi PHPMyAdmin 2.10.3 sebagai perangkat Database Management System (DBMS) untuk merancang basis data aplikasi alat ungkap pemahaman diri siswa secara fisikal. Hal ini dapat dilihat pada Tabel 3 sampai Tabel 9.

Tabel 3. Desain Tabel User

\begin{tabular}{|c|c|c|c|c|}
\hline No & Nama Atribut & Tipe & Ukuran & Keterangan \\
\hline 1 & Id_User* & Varchar & 6 & Primary Key \\
\hline 2 & Username & Varchar & 12 & \\
\hline 3 & Password & Varchar & 16 & \\
\hline \multicolumn{3}{|r|}{ Total } & 34 & \\
\hline \multicolumn{5}{|c|}{$\begin{array}{c}\text { Dengan asumsi pengisian data user dilakukan untuk } 4 \text { guru BK dan } \pm 40 \text { siswa } * 8 \text { kelas } * 3 \text { tingkat } \\
\text { sebagai user, maka estimasi disk space yang dibutuhkan dapat dihitung dengan cara: } \\
34 \text { karakter } \mathbf{x}(\mathbf{4} \text { guru }+\mathbf{9 6 0} \text { siswa) }=32776 \text { bytes }\end{array}$} \\
\hline
\end{tabular}

Tabel 4. Desain Tabel Siswa

\begin{tabular}{|c|c|c|c|c|}
\hline No & Nama Atribut & Tipe & Ukuran & Keterangan \\
\hline 1 & NIS* & Varchar & 5 & Primary Key \\
\hline 2 & Id_User** & Varchar & 6 & Foreign Key dari Tb_User \\
\hline 3 & Kelas & Varchar & 7 & \\
\hline 4 & Nama_Siswa & Varchar & 30 & \\
\hline 5 & Jkel & Char & 1 & \\
\hline 6 & Tempat_Lahir & Varchar & 15 & \\
\hline 7 & Tgl_Lahir & DateTime & 10 & \\
\hline 8 & Alamat & Varchar & 50 & \\
\hline 9 & Telepon & Varchar & 15 & \\
\hline \multicolumn{3}{|r|}{ Total } & 139 & \\
\hline \multicolumn{5}{|c|}{ 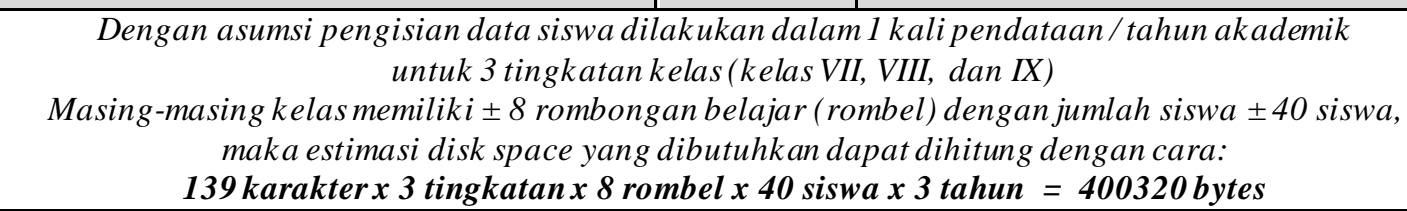 } \\
\hline
\end{tabular}


Tabel 5. Desain Tabel Guru BK

\begin{tabular}{|c|c|c|c|c|}
\hline No & Nama Atribut & Tipe & Ukuran & Keterangan \\
\hline 1 & NIP* & Varchar & 16 & Primary Key \\
\hline 2 & Id_User** & Varchar & 6 & Foreign Key dari Tb_User \\
\hline 3 & Nama_GuruBK & Varchar & 30 & \\
\hline 4 & Jkel & Char & 1 & \\
\hline 5 & Alamat & Varchar & 50 & \\
\hline 6 & Telepon & Varchar & 15 & \\
\hline & & Total & 118 & \\
\hline \multicolumn{5}{|c|}{$\begin{array}{c}\text { Dengan asumsi pengisian data guru BK dilakukan untuk4 orang guru BK, } \\
\text { maka estimasi disk space yang dibutuhkan dapat dihitung dengan cara: } \\
\mathbf{1 1 8} \text { karakter } \boldsymbol{x} \mathbf{4} \text { guru }=\mathbf{4 7 2} \text { bytes }\end{array}$} \\
\hline
\end{tabular}

Tabel 6. Desain Tabel Pernyataan Pemahaman Diri Siswa

\begin{tabular}{|c|c|c|c|c|}
\hline No & Nama Atribut & Tipe & Ukuran & Keterangan \\
\hline 1 & No_Pernyataan & Varchar & 5 & Primary Key \\
\hline 2 & No_Angket & Varchar & 5 & Foreign Key dari Tb_Angket \\
\hline 3 & Pernyataan & Varchar & 30 & \\
\hline \multicolumn{3}{|r|}{ Total } & 40 & \\
\hline \multicolumn{5}{|c|}{$\begin{array}{l}\text { Dengan asumsi pengisian data Pernyataan dilakukan untuk } 28 \text { macampernyataan pemahaman diri } \\
\text { siswa, maka estimasi disk space yang dibutuhkan dapat dihitung dengan cara: } \\
40 \text { karakter } x 28 \text { pernyataan }=1120 \text { bytes }\end{array}$} \\
\hline
\end{tabular}

Tabel 7. Desain Tabel Sifat

\begin{tabular}{|c|c|c|c|c|}
\hline No & Nama Atribut & Tipe & Ukuran & Keterangan \\
\hline 1 & Id_Sifat & Varchar & 5 & Primary Key \\
\hline 2 & No_Angket & Varchar & 5 & Foreign Key dari Tb_Angket \\
\hline 3 & Menunjang & Varchar & 30 & \\
\hline 4 & Menghambat & Varchar & 30 & \\
\hline \multicolumn{3}{|r|}{ Total } & 70 & \\
\hline \multicolumn{5}{|c|}{$\begin{array}{l}\text { Dengan asumsi pengisian data Sifat dilakukan untuk } \\
\text { nacam sifat yang menunjang dan menghambat pencapaian cita-cita siswa, } \\
\text { timasi disk space yang dibutuhkan dapat dihitung dengan cara: } \\
\mathbf{7 0} \text { karakter } \boldsymbol{x} \mathbf{1 0} \text { sifat = } 700 \text { bytes }\end{array}$} \\
\hline
\end{tabular}

Tabel 8. Desain Tabel Angket Pemahaman Diri Siswa

\begin{tabular}{|c|c|c|c|c|}
\hline No & Nama Atribut & Tipe & Ukuran & Keterangan \\
\hline 1 & No_Angket & Varchar & 5 & Primary Key \\
\hline 2 & Id_Sifat & Varchar & 5 & Foreign Key dari Tb_Sifat \\
\hline 3 & No_Pernyataan & Varchar & 5 & Foreign Key dari Tb_PernyataanPDS \\
\hline 4 & NIS & Varchar & 5 & Foreign Key dari Tb_Siswa \\
\hline 5 & Citacita & Varchar & 20 & \\
\hline 6 & In_Menunjang & Varchar & 20 & \\
\hline 7 & Dec_Menghambat & Varchar & 20 & \\
\hline 8 & Sifat_Dipelihara & Varchar & 20 & \\
\hline 9 & SL_Selalu & Char & 1 & \\
\hline 10 & KD_Kadang2 & Char & 1 & \\
\hline 11 & TP_TdkPernah & Char & 1 & \\
\hline \multicolumn{3}{|r|}{ Total } & 103 & \\
\hline \multicolumn{5}{|c|}{$\begin{array}{c}\text { Dengan asumsi pengisian data Angket PDS dilakukan untuk } \pm 40 \text { siswa * } 8 \text { kelas * } 3 \text { tingkatan } \\
\text { dalam } 1 \text { kali pendataan / tahun akademik, maka estimasi disk space yang dibutuhkan dapat dihitung } \\
\text { dengan cara: } 103 \text { karakter } \mathbf{x} 40 \text { siswa } \mathbf{x} \text { kelas } \mathbf{x} 3 \text { tingkatan = } 98880 \text { bytes }\end{array}$} \\
\hline
\end{tabular}




\section{DAFTAR PUSTAKA}

[1] Peraturan Menteri Pendidikan Nasional Republik Indonesia No.39 Tahun 2008 Tentang Pembinaan Kesiswaan.

[2] Hidayati, A., 2013, Perancangan dan Pembuatan Aplikasi Pendaftaran Mahasiswa Baru, Jurnal ELTEK, Vol11, No 02.

[3] Abdillah, L. A., 2006, Perancangan Basis Data Sistem Informasi Penggajian, Jurnal Imiah MATRIK, Vol 8 No 2, Hal 135-152.

[4] Indrajani, 2011, Perancangan Sistem Basis Data Pada Klinik, Jurnal ComTech, Vol 2 No 1, Hal 218-228.

[5] Handayani, F. S., 2014, Perancangan Basis Data Website Wedding Organizer Sekapur Sirih, Jurnal TEKNOMATIKA, Vol4, No 3.

[6] Robby, Kwanentent, O., Wardana, F. M., 2009, Analisis dan Perancangan Basis Data Untuk Mendukung Aplikasi ERP Education Pada Bina Nusantara University, Jurnal Bina Nusantara University.

[7] Gat, 2015, Perancangan Basis Data Perpustakaan Sekolah dengan Menerapkan Model Data Relasional, Citec Journal, Vol 2, No 4.

[8] Joefrie, Y. Y., Kalatiku, P.P., 2012, Desain Basis Data Sistem Informasi Akademik Di Fakultas Teknik Universitas Tadulako, Jurnal Ilmiah Foristek, Vol 2, No 21, Hal 190-194.

[9] Prasetya, W. S., 2015. Perancangan Model Basis Data Relasional Dengan Metode Database Life Cycle. Seminar Nasional Informatika (SEMNASIF), 14 November 2015, UPN Veteran Yogyakarta.

[10] Connoly, T., Begg, C., 2010, Database System: A Practical Approach to Design, Implementation, and Management, Fifth Edition, Pearson Education, Boston.

[11] Laudon, K. C., Laudon, J. P. 2005, Management Information Systems: Managing The Digital Firm, 8th edition, Prentice Hall, New Jerse. 